\title{
CORRESPONDENCE
}

\section{Brazilian funds}

\section{SIR - I would like to correct some of the} statements made by Mr Bazin in his article "Brazilian research funds: Sliding backwards" (Nature 6 August, p.489).

First, the Brazilian government has a clear and explicit policy statement regarding science and technology. This was published in the form of the 3rd Basic Plan for Scientific and Technological Development (1980-85) and stated in the 3rd National Development Plan.

Second, the Brazilian government, in harmony with the high priority given to science, has maintained a steady and growing support for scientific and technological activities. Financial resources allocated to science and technology in the federal budget are shown in Table 1.

Table 1 Federal support for science and technology

Science and technology budget

$\%$ Of

Year

1980

1981

(US\$ million)

352

federal budget

$2.1 \%$

435

$2.3 \%$

1982

$909^{*}$

$3.6 \%$

*Proposal now in discussion in Congress.

Third, the National Research Council (CNPq) which is the central coordinating agency for science and technology in Brazil, has had and has now an important role to maintain and reinforce this growing public

\section{Table 2 CNPq's budget}

\begin{tabular}{|c|c|c|}
\hline Year & $\begin{array}{l}\text { Total budget } \\
\text { (US\$ million) }\end{array}$ & $\begin{array}{l}\text { \% Allocated for } \\
\text { grants and } \\
\text { scholarships }\end{array}$ \\
\hline 1980 & 122 & $31.9 \%$ \\
\hline 1981 & 144 & $33.7 \%$ \\
\hline 1982 & $188^{*}$ & $38.0 \%$ \\
\hline
\end{tabular}

*Proposal.

support for research in the country. The data in Table 2 show that CNPq's budget, as well as the resources allocated for grants and scholarships, have outpaced inflation.

Erno Ivan Paulinyi

\section{CNPq, Brasilia, Brazil}

Maurice Bazin repl.ies - When considering whether Brazil's research spending has kept pace with inflation it should be remembered that inflation in Brazil was over 80 per cent in 1980 and is now around 110 per cent.

\section{Gold standard}

StR - The reexamination of the gold standard in the United States is motivated by more serious concerns than your article on the subject suggested (Nature 24 September, p.246). For, despite its faults, the gold standard performed an essential function for which no other arrangement has so far been able to substitute in a democracy. It provided an impartial mechanism which the general public accepted as justification for the monetary discipline necessary to prevent accelerating inflation.

From 1717, when Sir Isaac Newton established the official buying and selling prices of gold at $77 / 9 \mathrm{~d}$ and $77 / 10 \mathrm{1} / 2 \mathrm{~d}$ per troy ounce, until the outbreak of the First World
War in 1914 (apart from a period around the Napoleonic Wars), a pound sterling was worth $1 / 4$ ounce of gold (within 1 per cent), and it was universally accepted that the Bank of England should maintain adequate reserves of gold to guarantee sterling's convertibility. Thus, when official gold reserves fell below a prudent level, the steps necessary to increase them, including in particular the raising of interest rates, were accepted by the public (and the parliamentary opposition) in preference to the abandonment of the gold standard.

By contrast, since the last link with gold was broken in 1971, there has been no economic "yardstick" which is publicly accepted as an objective measure of sound monetary policy, and periods of economic difficulty are blamed on the incumbent government rather than on our own behaviour. Politicians have inevitably tried to "buy" popularity, and as a result, in only ten years, sterling has been devalued by 75 per cent in real terms, at terrible economic and social cost to the United Kingdom. The United States is surprisingly close behind.

There is, in fact, a very great need to link currency to a real measure of value in a system of which the soundness and impartiality are beyond question and clear to both public and politicians. However, the standard should not be some "short-lived exotic radioactive isotope" as you suggest, but should be a range of the durable, essential, basic commodities on which all economic activity depends. The many far-reaching advantages of such a policy have been described by a number of economists over the past century, but the specification of a practical system is complicated by the need for commodity prices to respond to market forces; they cannot be fixed as was the price of gold. Nevertheless it would be possible to achieve the desired results by establishing a rule by which official buying and selling prices of specified commodities were adjusted automatically according to the levels of official reserves. Such a system has been widely endorsed by economists from across the political spectrum, one writing in 1958: "It can be only a question of time before man's reason and self-interest overcome his inertia and these proposals are accepted. When they are they will define the beginning of an era as surely as did the introduction of the gold standard, but without its fatal weakness".

Institutional resistance to change has so far prevented the adoption of such an innovation. But until we do, inflation will continue, with all its destructive consequences (and economics will continue to be as unscientific as physics would be without the ruler).

P.Q. COLLINS

Imperial College of Science and Technology, London, UK

\section{Lab animals}

SIR - Your article on "Protection for laboratory animals"' (Nature 17 September, p.173) offers an ineffectual solution to the problem of how to regulate the use of animals in research. Your suggestion of establishing a committee at each institution empowered to sanction proposed uses of laboratory animals seems like an attempt to eliminate regulation entirely. No research facility would refuse to sanction the use of animals for an experiment in which funding has been previously granted.
For regulation to be effective, it must be done by the agency responsible for funding.

Ignoring humane and philosophical considerations, the need for regulation is generated by the sheer numbers of research facilities in existence today. In order to prevent wasteful duplication of experiments, a coordinating agency must be empowered to determine the usefulness of a particular project. Since public monies are usually involved, the usefulness and more importantly the uniqueness of a study must be determined. Of course, a certain amount of replication of experimental results is necessary, but as there is virtually no communication between facilities, a parent agency must be involved to keep track of who is doing what.

Wc have a responsibility to the animal community, from which we have gained much information at the expense of much suffering, to use individuals as prudently as possible. Whether or not you believe an animal is capable of suffering in human terms is not important. It is a living entity, entitled to the life it was designed to lead.

Regulation of the use of animals in research experiments is essential to assure the proper use of public funds as well as the compliance with laws governing the humane treatment of the subjects. A governmental body,

specifically the agency responsible for funding of research projects, must be responsible for the regulations. JACKiE ALAN GIULIIANO Jet Propulsion Laboratory/California

Institute of Technology, Los Angeles, California, USA

SIR - I was pleased to see your editorial comment "Protection for laboratory animals?" (Nature 17 September, p.173). The Committee for the Reform of Animal Experimentation (CRAE), which is drawn from both houses of parliament and from the fields of science and medicine as well as animal welfare, has been seeking contact with members of the scientific community at all levels in order to find a "middle ground" where there can be agreement on many of the issues relating to the use of living animals for research. We would be very pleased to hear from those working with animals in laboratories if they have any points of view to express.

CRAE applauds your proposal for the setting up of ethical committees within research centres to act as a brake on undesirable experimentation. Such committees should be largely composed of researchers' peers but should also include what the courts describe as "the reasonable man", that is, responsible members of the local community.

The concept of ethical committees would fit very well with the Home Secretary's Advisory Committee proposals for a project licence as a requirement as well as a competence licence before a researcher could experiment.

One error in your editorial: although the 1876 Act requires experiments involving pain to be carried out under anaesthesia, such provision is the subject of exemption by the issue of Certificate " $A$ " which permits the infliction of either severe or enduring pain, and it is only where an animal is found to be suffering severe and enduring pain that the experiment must be terminated.

Clive Holi. Ands

Committee for the Reform of Animal

Experimentation, Edinburgh, UK 